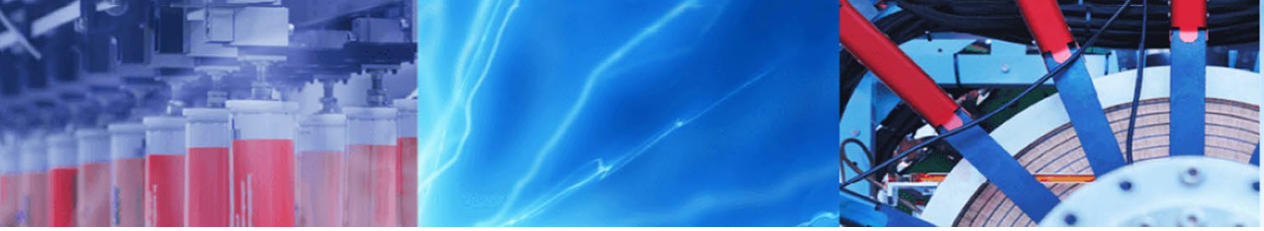

Short Communication

\title{
Polycyclic aromatic hydrocarbons in the bottom sediments of Elburgon River-Kenya: precursors for cancer
}

\author{
Francis E. Opuru ${ }^{1}$. Joshua K. Kibet ${ }^{1}$ (I) $\cdot$ Samuel K. Kirkok ${ }^{1} \cdot$ Silas M. Ngari ${ }^{1}$
}

(c) Springer Nature Switzerland AG 2019

\begin{abstract}
The exponential growth in the rate of industrialization is a serious precursor for contamination and deterioration of the environment. Water pollution, for instance, is expected to reach disturbing levels in the years to come. Polycyclic aromatic hydrocarbons (PAHs) in water systems are persistent contaminants not only in aquatic systems but also in soil, air and plant materials and are well-known initiators for cancer and gene mutation. Numerous human-dependent activities such as agriculture and suspected wood treatment works in Elburgon may lead to an increased PAH contamination of water in River Elburgon, especially when the internationally set limits are exceeded. The sediment samples were collected in May 2019 during the wet season and treated for analysis of PAHs using a gas chromatograph hyphenated to a mass selective detector. A total of $25 \mathrm{PAHs}$ were quantified in this study out of which pyrene was the most abundant, contributing $\approx 17 \%$ of the total concentrations of PAHs identified. The total concentration of the PAHs analyzed in this study was found to be $\sum_{25} \mathrm{PAH}=73.19 \pm 3.67 \mu \mathrm{g} \mathrm{g}^{-1}$ dry weight $(\mathrm{dw})$ with pyrene contributing a total concentration $\sum_{\text {pyrene }}=12.44 \pm 0.54 \mu \mathrm{g} \mathrm{g}^{-1} \mathrm{dw}$. On the other hand, benzo[a]pyrene (BaP)—a well-known carcinogen-was significantly high $\sum_{\mathrm{BaP}}=10.67 \pm 0.43 \mu \mathrm{g} \mathrm{g}^{-1}$. Other major PAHs detected included acenaphthene and 5,6-dihydrobenzo[de] anthracene, $14.57 \%$ and $\approx 11 \%$, respectively. The low concentration PAHs included 1-ethenylnaphthalene and 1,4,5-trimethylnaphthalene each at $0.08 \%$. The presence of benzo[a]pyrene in significant amounts is of serious concern on the public health of the residents of Elburgon and its environs. Considering the high levels of PAHs in the sediments of River Elburgon, it is important to note with concern that the water in the river under study is not only be unsuitable for drinking but also unsuitable for other domestic purposes such as irrigation and laundry.
\end{abstract}

Keywords Benzo[a]pyrene $\cdot$ Contaminants $\cdot$ Sediment $\cdot$ Water pollution

\section{Introduction}

The world has in the recent years witnessed drinking water pollution incidents that have occurred regularly partly because of intentional pollution, accidental chemical pollution such as oil spills and biological pollution which are a threat to human health, social stability and security of consumers [1]. The concentration and PAH distribution in the Kenyan water basins, and especially the River Molo water basin, are poorly studied. Therefore, it is against this concern that significant attention is necessary in the assessment of polycyclic hydrocarbon (PAH) pollution as beacons for water quality. In this investigation, PAHs are explored quantitatively from Elburgon River (Nakuru County-Kenya) that passes near a wood treatment plant and an agricultural-rich area. These chemicals (PAHs) are largely teratogenic, carcinogenic and mutagenic and may induce cancer in biological systems, pain and oxidative stress during metabolism [2].

There are no known research data on the level of PAH in River Elburgon, and consequently, this study reports the first PAH data in the river. Nevertheless, studies conducted

Joshua K. Kibet, jkibet@egerton.ac.ke; Francis E. Opuru, francisopuru2013@gmail.com; Samuel K. Kirkok, kirkokkipyegon@gmail.com; Silas M. Ngari, sngari@egerton.ac.ke | 'Department of Chemistry, Egerton University, P.O. Box 536-20115, Egerton, Kenya.

SN Applied Sciences (2019) 1:1270 | https://doi.org/10.1007/s42452-019-1321-7

Received: 1 July 2019 / Accepted: 18 September 2019 / Published online: 24 September 2019 
elsewhere for example on quality of drinking water of Tehran (Iran) indicated that high molecular weight PAHs constituted the highest concentration (79.55\%) of all the PAHs analyzed [2]. These results corroborate the data reported in this work which suggest that the total concentration of high molecular weight PAHs is $\approx 53.31 \%$ and may be characteristic of petrogenic sources. Nonetheless, whereas the data reported in Tehran targeted drinking water, the data reported in this study were that of sediments in River Elburgon. There is, however, a good correlation between PAHs in the water phases and the sediment phase or colloidal phases because PAHs are not completely insoluble, and consequently, significant amounts of PAHs dissolve in water and thus become bioavailable [3]. Moreover, a study in Xiamen Island, China, indicated high concentrations of benzo[a]pyrene suspected to originate from oil spills and possibly other petrogenic sources [4]. Kafilzadeh (2015) reported fluoranthene (four-ring PAH) was the most important pollutant with mean concentrations ranging from 27.33 to $65.24 \mathrm{ng} \mathrm{g}^{-1}$ in four stations, respectively, in Abad River, Iran [3]. Interestingly, fluoranthene and anthracene were not detected in the present study possibly because they were below the detection limit of the GCMS instrument used. More recently, an investigation of the residual characteristics, sources and ecological risks of PAHs in sediment from 15 typical sites from Qinhuai River and Xuanwu Lake typical urban rivers and lakes collected from October 2015 to July 2016 showed that $\sum$ PAHs concentration in sediment ranged from 796.2 to $10,470 \mathrm{ng} \mathrm{g}^{-1}$ with an average of $2713.8 \mathrm{ng} \mathrm{g}^{-1}$ [5]. However, the concentrations reported in this study are significantly higher than most of the PAH levels reported elsewhere, suggesting a direct source of PAH precursors into River Elburgon. The establishment of wood treatment plants and a rich horticultural regime along the river is suspected to be the origin of these PAHs although continuous monitoring of these chemicals in the river is encouraged to firmly ascertain their sources.

Due to their high toxicity and abundance in the environment, including water, soils and sediments, PAHs have been listed as priority pollutants by the United States Environmental Protection Agency (US EPA) [6, 7]. They are of critical environmental and public health concern because of their toxic, genotoxic, mutagenic or carcinogenic properties and their ubiquitous occurrence as well as resistance in the environment [8]. From a chemical standpoint, PAHs are a class of diverse compounds consisting of two or more benzene rings bonded in linear, cluster or angular arrangements and may be substituted or unsubstituted by hydrocarbon alkyl groups $[9,10]$. It is noted in the literature that creosote in contact with soil and water undergoes a series of toxicokinetic and photoinduced toxicities in the presence of visible and ultraviolet radiations to form highly hazardous species [11] such as phenoxyl radicals and other transient reactive intermediate from benzo[a] pyrene, pyrene, dibenzo[ah]anthracene, fluorene and other PAHs which form the primary focus of this study.

There is an increased probability of mutagenesis, especially when a person inhales, ingests or dermally gets in contact with PAHs $[12,13]$. When wood treatment chemicals are used, PAH concentrations may be elevated through accidental spillage of the chemicals, poor disposal of sludge (creosote waste) and other wood preservative concoctions. These hazardous wastes eventually leach into the soil and water resources and may be taken up by plants and aquatic organisms [14]. Due to accumulative and persistence nature, PAHs get into the fatty tissues of animals and plants and ultimately to the natural food chains in a cycle of trophic events [15]. The PAHs get absorbed in the gastrointestinal tract where the biotransformation enzymes and cytochrome P450 oxidase (CYP) suite activate the initiation of the carcinogenic PAHs to more toxic intermediates [16], while in the body of animals, the carcinogenic effect of PAHs makes them entangled with the DNA forming PAH-DNA in genotoxic and epigenetic events $[17,18]$. PAHs in general are metabolized by CYPs and other enzymes into phenols, catechols and quinones considered precursors for the formation of diolepoxides, radical cations and redox-active oquinones, which ultimately react with DNA to produce DNA adducts responsible for gene mutation and tumorigenesis [19].

The World Health Organization (WHO) and the UK Expert Panel on Air Quality Standards (EPAQS) have considered benzo[a]pyrene, a group 1 carcinogen, as a marker for carcinogenic potency among polycyclic aromatic hydrocarbon (PAH) mixture when recommending guidelines for PAH toxicity in various environments including water systems [20,21]. Accordingly, benzo[a]pyrene is listed as an endocrine disruptor in the environmental hormone group [22]. Furthermore, pyrene just like other PAHs in water environments is a major concern due its possible toxic nature and abundance [23]. Because of their known toxicity, the US Environmental Protection Agency (US EPA) and the International Agency for Research of Cancer (IARC) classified some PAHs including benzo[a]pyrene, pyrene and benzo[def]fluorene among others, as probable human carcinogens and mutagens [20,22]. This implies that the presence of these chemicals in water systems may cause serious biological diseases because they can be metabolized in the body systems into harmful quinones and other toxic chemicals [24].

The suitability of River Elburgon water for drinking, irrigation and industrial purposes is a subject of concern, especially from suspected PAH pollutants. These pollutants are proposed to originate from horticultural and suspected wood treatment activities in Elburgon. 
Accordingly, this investigation has explored the origin of the PAH chemicals in the sediments of River Elburgon that may impact negatively on human health and aquatic life. Based on the results reported, it is clear that the PAH sources in this study may be traced to petrogenic regimes such as a wood treatment plant, oil spills and agrochemicals. For instance, the presence of anthracene in the sediments is a finger print suggesting a wood preservative source while the presence of acenaphthene and fluorene confirms a pesticide origin [25]. Wood treatment sites, for instance, are known to use chemicals that release PAHs into the soil and water environments which ultimately cause significant health impacts in the natural food chain [26]. The suspected wood treatment chemical applied in wood treatment works around Elburgon is creosote and/ or pentachlorophenol which are considered major precursors for PAHs [27]. Therefore, the PAH pollution source in River Elburgon is probably precipitated by humandependent activities. This study is therefore necessary in sensitizing the general public on the water quality of River Elburgon-a major source of drinking water for the local population residing in the western part of Nakuru County and the residents living within the Molo water basin.

This research work was carried out on Elburgon River (a tributary of the larger Molo River). The wood treatment plant proposed to be the origin of the PAHs identified in this study is located on the GIS coordinates, E036 $14.813^{\prime}$ S00 $21.998^{\prime}$ at an average elevation of 2124 meters above sea level (masl). The wood treatment site lies on the floor of the Kenyan Rift Valley in Nakuru County.

\section{Materials and methods}

Hexane and methanol and certified PAH standards (for calibration) which were of analytical grade and purity $\geq 98 \%$ were procured from Sigma Aldrich Inc. (St. Louis, Missouri, USA). Soil sediments were collected from River Elburgon that passes near Elburgon town within the Molo water basin (Nakutu County, Kenya). Five sample collection points at intervals of about 500 meters were selected. The sediment samples were collected weekly for a period of one month in triplicates during the wet season-May 2019. The soil sample was collected using sterilized trowels, plastic bags. Soil sediments were air dried in a dark room for $96 \mathrm{~h}$ in order to avoid the degradation of volatile components [28]. Dried samples were then ground using a mortar and a pestle and then sieved using a molecular sieve of 50 microns. Twenty grams $(20 \mathrm{~g})$ of the soil samples was weighed using an analytical balance, placed in a thimble and covered with cotton wool followed by extraction using Soxhlet method, and the mantle supplied heat under an operating temperature of between 50 and $80^{\circ} \mathrm{C}$.
This low temperature range was recommended to avoid the decomposition of thermally unstable organic components. A binary mixture of methanol and hexane was used as solvents during extraction in the ratio of $3: 4 \mathrm{v} / \mathrm{v}$. The extraction process was run for $48 \mathrm{~h}$ to complete the extraction process. The extract was filtered and cleaned using solid-phase extraction (SPE) technique and pre-concentrated using a rotor vapor followed by drying under a gentle flow of nitrogen at $30^{\circ} \mathrm{C}$ prior to storing in amber vials for GCMS analysis.

\subsection{Molecular characterization of PAHs}

The polycyclic aromatic hydrocarbons (PAHs) reported in this work were characterized using an Agilent Technologies 7890A GC system connected to an Agilent Technologies $5975 \mathrm{C}$ inert XL electron ionization/chemical ionization (EI/Cl) with a triple-axis mass selective detector (MSD) on total ion current (TIC) mode using a HP-5MS GC column $(30 \mathrm{~m} \times 250 \mu \mathrm{m} \times 0.25 \mu \mathrm{m})$ [19]. The temperature of the injector port was set at $250^{\circ} \mathrm{C}$ in order to convert all the organic components into the gas phase. Helium was used as the carrier gas at the flow rate of $3.3 \mathrm{~mL} \mathrm{~min}^{-1}[20] .2 \mu \mathrm{L}$ of sample was injected in the split ratio 50:1. The details of this procedure are captured elsewhere in the literature $[28,29]$. The samples were run through a GCMS system in replicates to ensure consistency in data collection. Standards of pure compounds of interest were used to guarantee that the target molecular compounds were positively identified based on fragmentation pattern and retention times. External standards were used to construct calibration curves for quantitation of the PAHs reported in this work. The $R^{2}$ values ranged between 0.998 and 0.999. To ensure the validity of the data, pure model compounds were run through the GCMS system under similar conditions as the sample and recoveries of between 95 and $104 \%$ were obtained. These recoveries were good enough to qualify the analytical data reported in this study and rule out any chemical interference. All GCMS data reported in this study were an average of three replicates. The limit of detection (LOQ) for the GCMS instrument for most PAHs was on average $0.0001 \mu \mathrm{g} \mathrm{g}^{-1}$ while the limit of quantitation (LOD) was $0.0005 \mu \mathrm{g} \mathrm{g}^{-1}$. The PAH results are reported as an average for the sampled areas (1-5) along the River Elburgon (Fig. 1).

\section{Results and discussion}

The total concentration of each polycyclic aromatic hydrocarbon (PAH) in five sampling points along River Elburgon is reported with the chief aim of providing a general concern of their distribution in the river sediments. 


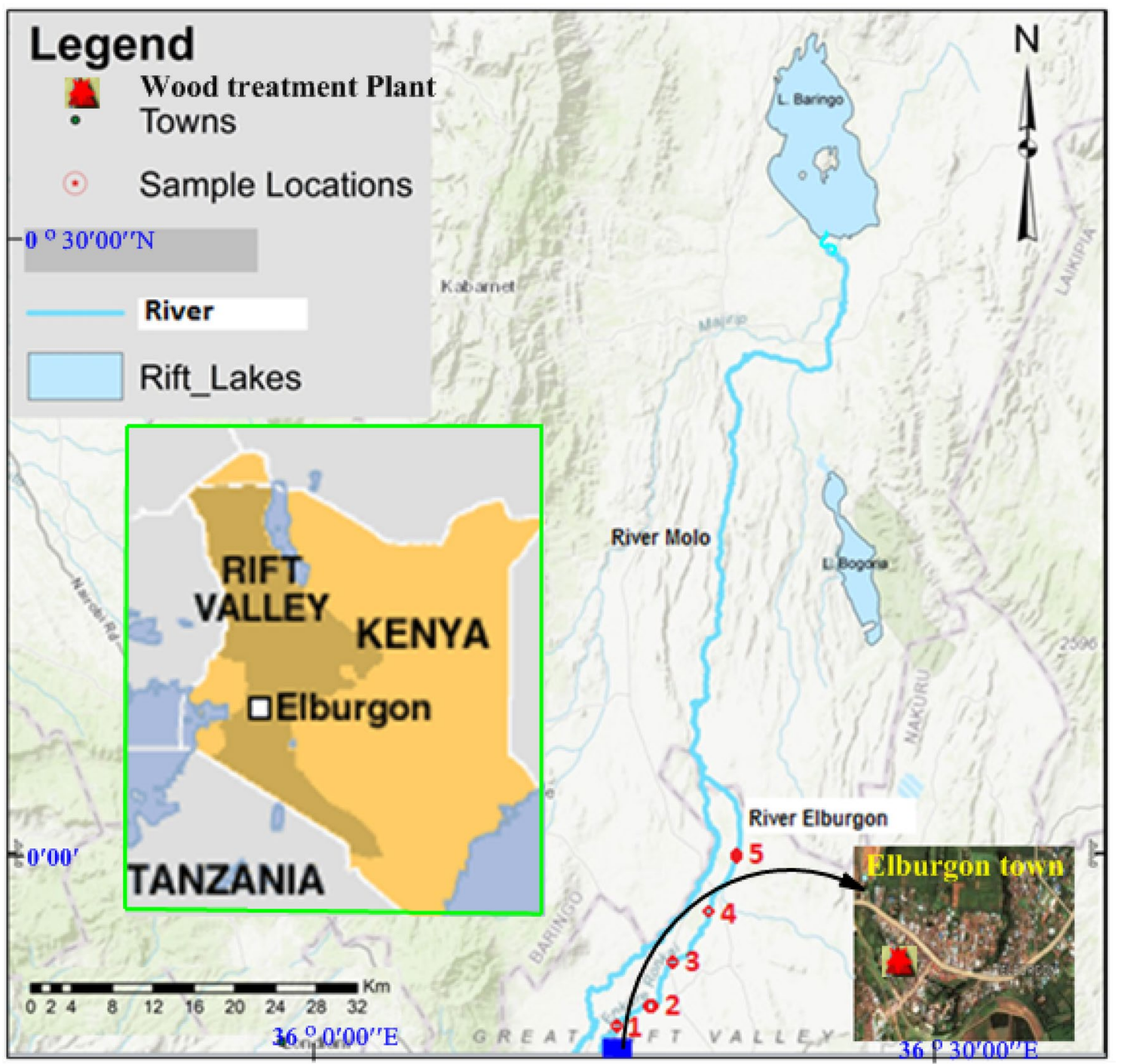

Fig. 1 A map of River Elburgon showing the sampling points-1, 2, 3, 4, 5 (inset is the map of Kenya and the location of Elburgon town)

Accordingly, the occurrence and quantitative analysis of 25 PAHs in the sediments of River Elburgon of the Molo water basin, Nakuru County, are remarkable and form the basis for intense discussion in this work. From a chemical perspective, polycyclic aromatic hydrocarbons (PAHs) are a class of xenobiotic compounds consisting of carbon and hydrogen and represent a group of contaminants with high risk ability to cause cancer, oxidative stress and endocrine disruption [2]. Moreover, their potent toxicity varies markedly between congeners [30,31].

The total average concentration of the PAHs analyzed in this study was found to be $\sum_{25} \mathrm{PAH}=73.19 \pm 3.67 \mu \mathrm{g} \mathrm{g}^{-1}$ dry weight $(\mathrm{dw})$ with pyrene, benzo[a]pyrene and 5,6-dihydrobenzo[de]anthracene contributing about $17 \%$, $14.57 \%$ and $13.18 \%$, respectively (cf. Table 1). These results suggest the suitability of benzo[a]pyrene as a marker for carcinogenic potential of the PAH mixture in water quality studies [32]. The high molecular weight (HMW) PAHs are more detrimental to public health because of their persistence in the environment, molecular stability, high hydrophobicity and their high binding ability to fatty tissues in biological systems [33]. Table 1 presents the molecular structures of high molecular weight PAHs. The low molecular weight (LMW) PAHs have been grouped into two in this study-groups I and II. Group I PAHs consist mainly of two-ring and a few three-ring PAHs with molecular masses ranged $142.08-168.08 \mathrm{~g} \mathrm{~mol}^{-1}$. This category constitutes $\sum_{12} \mathrm{PAH}=21.82 \pm 0.92 \mu \mathrm{g} \mathrm{g}^{-1} \mathrm{dw}$ with acenaphthene and 1-methylethenylnaphthalene contributing the highest mean concentrations of $8.05 \pm 0.22 \mu \mathrm{g} \mathrm{g}^{-1}$ and $6.54 \pm 0.25 \mu \mathrm{g} \mathrm{g}^{-1}$, respectively.

Besides, group II PAHs (Table 1) consist of eight molecular aromatic compounds of mainly three rings with the exception of benzo[def]fluorene which has four rings 
Table 1 PAH concentrations in bottom sediments of the River Elburgon in stations S1-S5 in May 2019

\begin{tabular}{|c|c|c|c|c|c|c|c|}
\hline \multirow[t]{2}{*}{$\mathrm{S} / \mathrm{N}$} & \multirow[t]{2}{*}{ Compound name } & \multirow{2}{*}{$\begin{array}{l}\text { Molar mass } \\
\left(\mathrm{g} \mathrm{mol}^{-1}\right)\end{array}$} & \multicolumn{5}{|c|}{ Concentrations $\left(\mu \mathrm{g} \mathrm{g}^{-1}\right)$ at various collection stations } \\
\hline & & & S1 & S2 & S3 & S4 & S5 \\
\hline 1 & 1-methyl naphthalene & 142.08 & $0.18 \pm 0.02$ & $0.14 \pm 0.02$ & $0.12 \pm 0.01$ & $0.09 \pm 0.01$ & $0.07 \pm 0.01$ \\
\hline 2 & biphenyl & 154.08 & $0.29 \pm 0.04$ & $0.25 \pm 0.02$ & $0.22 \pm 0.02$ & $0.17 \pm 0.03$ & $0.11 \pm 0.02$ \\
\hline 3 & 2,3-dimethylnaphthalene & 156.09 & $0.18 \pm 0.02$ & $0.13 \pm 0.01$ & $0.10 \pm 0.01$ & $0.08 \pm 0.02$ & $0.06 \pm 0.01$ \\
\hline 4 & 1-ethenylnaphthalene & 154.08 & $0.09 \pm 0.03$ & $0.07 \pm 0.01$ & $0.06 \pm 0.01$ & $0.05 \pm 0.01$ & $0.03 \pm 0.01$ \\
\hline 5 & acenaphthylene & 152.06 & $3.95 \pm 0.28$ & $3.70 \pm 0.26$ & $3.65 \pm 0.20$ & $3.15 \pm 0.21$ & $3.00 \pm 0.11$ \\
\hline 6 & acenaphthene & 154.08 & $8.90 \pm 0.22$ & $8.40 \pm 0.28$ & $8.20 \pm 0.24$ & $7.60 \pm 0.18$ & $7.15 \pm 0.16$ \\
\hline 7 & 1-allylnaphthalene & 168.09 & $0.78 \pm 0.05$ & $0.68 \pm 0.02$ & $0.68 \pm 0.04$ & $0.53 \pm 0.13$ & $0.38 \pm 0.03$ \\
\hline 8 & 1-methylethenylnaphthalene & 168.08 & $7.94 \pm 0.47$ & $7.22 \pm 0.11$ & $6.57 \pm 0.22$ & $5.85 \pm 0.23$ & $5.12 \pm 0.21$ \\
\hline 9 & 2,3,6-trimethylnaphthalene & 170.11 & $1.83 \pm 0.20$ & $1.68 \pm 0.19$ & $1.48 \pm 0.15$ & $1.39 \pm 0.15$ & $1.27 \pm 0.13$ \\
\hline 10 & 1,4,5-trimethylnaphthalene & 170.11 & $0.10 \pm 0.02$ & $0.08 \pm 0.01$ & $0.06 \pm 0.01$ & $0.04 \pm 0.01$ & $0.03 \pm 0.01$ \\
\hline 11 & fluorene & 166.08 & $0.82 \pm 0.07$ & $0.74 \pm 0.03$ & $0.56 \pm 0.03$ & $0.45 \pm 0.02$ & $0.33 \pm 0.04$ \\
\hline 12 & diphenylmethane & 168.08 & $0.65 \pm 0.06$ & $0.54 \pm 0.01$ & $0.45 \pm 0.03$ & $0.34 \pm 0.01$ & $0.27 \pm 0.02$ \\
\hline 13 & 1-benzyl-3,5-dimethylbenzene & 196.13 & $0.32 \pm 0.02$ & $0.27 \pm 0.01$ & $0.23 \pm 0.01$ & $0.19 \pm 0.01$ & $0.14 \pm 0.01$ \\
\hline 14 & 1-methyl-9H-fluorene & 180.09 & $0.96 \pm 0.04$ & $0.88 \pm 0.02$ & $0.82 \pm 0.02$ & $0.68 \pm 0.02$ & $0.61 \pm 0.05$ \\
\hline 15 & 9-methyl-9H-fluorene & 180.09 & $2.89 \pm 0.12$ & $2.68 \pm 0.13$ & $2.57 \pm 0.11$ & $2.32 \pm 0.10$ & $2.14 \pm 0.11$ \\
\hline 16 & phenanthrene & 178.08 & $0.72 \pm 0.07$ & $0.59 \pm 0.03$ & $0.44 \pm 0.04$ & $0.36 \pm 0.02$ & $0.29 \pm 0.01$ \\
\hline 17 & 1-methylphenanthrene & 192.09 & $5.61 \pm 0.25$ & $4.82 \pm 0.23$ & $4.21 \pm 0.17$ & $3.731 \pm 0.13$ & $2.93 \pm 0.12$ \\
\hline 18 & benzo[def]fluorene & 190.08 & $3.23 \pm 0.21$ & $2.81 \pm 0.20$ & $2.61 \pm 0.15$ & $2.06 \pm 0.08$ & $1.69 \pm 0.04$ \\
\hline 19 & 4-methylphenanthrene & 192.09 & $1.33 \pm 0.04$ & $1.08 \pm 0.02$ & $0.93 \pm 0.02$ & $0.74 \pm 0.03$ & $0.57 \pm 0.02$ \\
\hline 20 & 2,5-dimethylphenanthrene & 206.11 & $0.86 \pm 0.04$ & $0.80 \pm 0.01$ & $0.74 \pm 0.02$ & $0.59 \pm 0.20$ & $0.41 \pm 0.02$ \\
\hline 21 & pyrene & 202.25 & $14.19 \pm 0.52$ & $13.44 \pm 0.51$ & $12.37 \pm 0.44$ & $11.49 \pm 0.42$ & $10.80 \pm 0.38$ \\
\hline 22 & 5,6-dihydrobenzo[de]anthracene & 218.11 & $12.45 \pm 0.56$ & $11.15 \pm 0.47$ & $9.10 \pm 0.32$ & $8.30 \pm 0.38$ & $7.25 \pm 0.27$ \\
\hline 23 & 11H-benzo[c]fluorene & 216.09 & $2.59 \pm 0.08$ & $2.48 \pm 0.04$ & $2.29 \pm 0.13$ & $1.91 \pm 0.12$ & $1.68 \pm 0.12$ \\
\hline 24 & 1,3-dimethylpyrene & 230.11 & $4.91 \pm 0.92$ & $4.76 \pm 0.41$ & $4.26 \pm 0.53$ & $3.46 \pm 0.51$ & $3.01 \pm 0.42$ \\
\hline 25 & benzo[a]pyrene & 252.09 & $12.57 \pm 0.56$ & $11.62 \pm 0.48$ & $10.97 \pm 0.52$ & $9.47 \pm 0.23$ & $8.72 \pm 0.35$ \\
\hline$\sum_{25} \mathrm{PAH}$ & & & $88.34 \pm 4.91$ & $80.92 \pm 4.06$ & $73.69 \pm 3.45$ & $65.04 \pm 3.26$ & $57.94 \pm 2.68$ \\
\hline
\end{tabular}

and 1-benzyl-3,5-dimethylbenzene which has two rings. These chemicals constitute $\sum_{8} \mathrm{PAH}=12.36 \pm 0.76 \mu \mathrm{g} \mathrm{g}^{-1}$ dry weight $(\mathrm{dw})$. The highest PAH average concentration in this category was 1-methylphenanthrene $\left(4.26 \pm 0.02 \mu \mathrm{g} \mathrm{g}^{-1}\right)$ followed by benzo[def]fluorene with a mean concentration of $2.48 \pm 0.09 \mu \mathrm{g} \mathrm{g}^{-1} \mathrm{dw}$. This family of compounds have molecular masses ranged $196.13-206.11 \mathrm{~g} \mathrm{~mol}^{-1} \mathrm{dw}$ (Table 1). Evidently, this study has shown that 1-methyl naphthalene, biphenyl, 2,3-dimethylnaphthalene, acenaphthylene, 1-benzyl-3,5-dimethylbenzene and 1,4,5-trimethylnaphthalene were found in relatively low concentrations, $0.12 \pm 0.03,0.21 \pm 0.04,0.11 \pm 0.02,0.06 \pm 0.01,0.23 \pm 0.02$, and $0.06 \pm 0.01 \mu \mathrm{g} \mathrm{g}^{-1} \mathrm{dw}$, respectively. Nonetheless, some chemical pollutants, especially PAHs, are very toxic even at significantly low concentrations. The average compositional distribution of the PAHs under study ranged from $0.06 \pm 0.01 \mu \mathrm{g}$ to $12.46 \pm 0.45 \mu \mathrm{g} \mathrm{g}^{-1} \mathrm{dw}$.

It is evident from Table 1 that the concentration of PAHs in bottom sediment of the River Elburgon decreased downstream from check points $1-5$. This trend may be attributed to the fact that station 1 was near the wood treatment plant, and possible effluent discharge from Elburgon town. The variation in concentration along the River is markedly pronounced for all the contaminants, suggesting that possible addition from agricultural activities downstream is insignificant. Clearly, the results in Table 1 strongly indicate a point source such as a wood treatment plant or oil spills from a car wash regime which is common in Elburgon town. These results rule out other anthropogenic sources including wood burning (forest fires), pyrolytic sources or possible mining activities.

Accordingly, acanaphthylene, acenapthene, 1-methylethenylnaphthalene, 1-methylphanthrene, 5,6-dihydrobenzo[de]anthracene, pyrene, 1,3-dimethylpyrene and benzo[a]pyrene were consistently the major hydrocarbons in the Elburgon River in all the station samples with a total average concentration of $59.19 \pm 0.33 \mu \mathrm{g} \mathrm{g}^{-1} \mathrm{dw}$. These PAHs constitute approximately $80.87 \%$ of the total PAH concentrations determined in this study. The concentration of benzo[a]pyrene which is a well-known carcinogen and has been assigned 
a toxicological equivalent factor (TEF) of 1 because of its grave toxicological behavior [33, 34] varied between 14.19 and $10.80 \mu \mathrm{g} \mathrm{g}{ }^{-1} \mathrm{dw}$.

\subsection{PAH profiles in the sediments of River Elburgon}

This study identified 25 PAHs as reported in Table 1 which can be categorized in terms of the number of rings each PAH contains. The majority of the PAHs had two rings (10) while the three-ring PAHs were 9. The four-ring PAHs were 5, whereas the five-ring PAH was only 1 based on the findings of this study. Accordingly, two- and threering $\mathrm{PAH}$ constituted $76 \%$ of the PAHs identified while the four-ring PAHs constituted $20 \%$. The five-membered ring $\mathrm{PAH}$ was only $4 \%$ of the total $\mathrm{PAH}$ s reported in this work. On the other hand, $52 \%$ of the PAHs was substituted by alkyl groups out of which $40 \%$ was methyl substituted. The higher molecular weight PAHs were less substituted compared to the low molecular weight PAHs. Remarkably, three- and five-ring PAHs were the key contaminants in the sediments of Elburgon River with a contribution of $60 \%$ and a total concentration, $\sum_{15} \mathrm{PAH}=63.30 \pm 4.16 \mu \mathrm{g} \mathrm{g} \mathrm{g}^{-1} \mathrm{dw}$. Of the 25 PAHs detected, five PAHs were classified as high molecular weight PAHs and had a total average concentration $\sum_{5} \mathrm{PAH}=39.03 \pm 1.68 \mu \mathrm{g} \mathrm{g}^{-1} \mathrm{dw}$. The low molecular weight PAHs contributed $\sum_{20} \mathrm{PAH}=34.18 \pm 1.19 \mu \mathrm{g} \mathrm{g}^{-1} \mathrm{dw}$. Remarkably, the ratio of low molecular weight PAHs to high molecular weight $\mathrm{PAHs}$ was $\approx 1.15$. This ratio postulates that PAH contamination in the sediment originates primarily from petrogenic sources such as oil spills, hydrocarbon waste and possibly hydrocarbon-based agrochemicals [34]. To complement this observation, PAHs of petrogenic origins are characterized by the predominance of two- and three-ring PAHs, while the PAHs of pyrogenic origins are characterized by a high proportion of four-ring or heavier PAHs [35, 36]. This is consistent with the geographical location of River Elburgon in which there are suspected wood treatment activities, car washing and heavy agricultural activities. There are no known activities suggesting pyrolytic sources of $\mathrm{PAHs}$ in the area. It is interesting to note that the concentration of high molecular weight PAHs dominated the low molecular weight PAHs. From this study, the concentration of high molecular PAHs constituted $\approx 53.31 \%$ of the total PAHs quantified.

\subsection{Cyclopenta-fused PAHs and methyl-substituted PAHs and their biological action}

This study identified eight cyclopenta-fused polycyclic aromatic hydrocarbons which belong to a class of non-alternant polycyclic aromatic hydrocarbons. These compounds included fluorene, 1-methyl-9H-fluorene,
9-methyl-9H-fluorene, benzo[def]fluorene, $11 \mathrm{H}$-benzo[c] fluorene, acenaphthylene and acenaphthene (cf. Table 1). It is well established in the literature that cyclopenta-fused PAHs are more reactive than other PAHs and are considered biologically active chemicals because of their strong mutagenic and carcinogenic tendencies $[37,38]$. This proposition may be attributed to the strain in the cyclopenta ring attached to the rest of the PAH structure which may be electronically active and hence the origin of their biological activity. For this reason, cyclopenta-fused PAHs may have a rapid activity to cross biological membranes to cause oxidative stress, tissue damage and cancer. They are therefore potential precursors of reactive oxygen species (ROS) in biological environments. On the other hand, substituted PAHs are also considered very reactive because of the methyl group. The methyl group can easily be abstracted by a radical species such as semiquinone to form a methyl radical and a reactive transient species that may have serious biological implications. Generally, the most potent metabolites of PAHs are methyl-substituted hydrocarbons depending on the region of methylation [39]. Methylation must take place at the most reactive center (bay region) in the molecule for the molecule to be a potential carcinogen or mutagen. This study identified more than 12 substituted PAHs most of which have methyl substitutions in the electronic rich centers and thus potential precursors for carcinogenicity and other biological health concerns.

There are set allowable limits for PAHs in water systems according to the European Commission and US EPA [26, $32,39]$. For instance, according to the fact sheet prepared by the Agency for Toxic Substances and Disease Registry (ADSTR), the minimum limit for benzo[a]pyrene, an indicator, for PAH carcinogenicity in drinking water is $0.2 \mathrm{ppb}$ while the permissible limit for benzo[b]fluoranthene has been set at $0.0002 \mathrm{ppm}[24,39]$. The fact sheet also indicates the allowable limits for PAHs in sediments. Accordingly, this study has shown that the concentration of PAHs in sediments is significantly high and above the standards set by the European Commission and USEPA. Although the solubility of PAHs is considerably low in water, it is clear that high concentration of PAHs in sediments may enhance their solubility in water and consequently pose deleterious impacts to water consumers and aquatic ecosystems.

Generally, PAHs are semi-volatile compounds considered lipophilic and therefore exert both specific and nonspecific membrane effects $[10,40]$. Figure 2 illustrates the mechanistic interaction of quiones (metabolites of PAHs) with DNA to cause disease. Reactive oxygen species (ROS) are of grave concern because they have the ability to rapture biological tissues resulting in pain, oxidative stress and ultimately fatalities. Metabolism of PAHs is known 
Fig. 2 Alkylation and redox cycling of quinones generating adducts and $\operatorname{ROS}(29,30)$ (Nu-cellular nucleophiles)

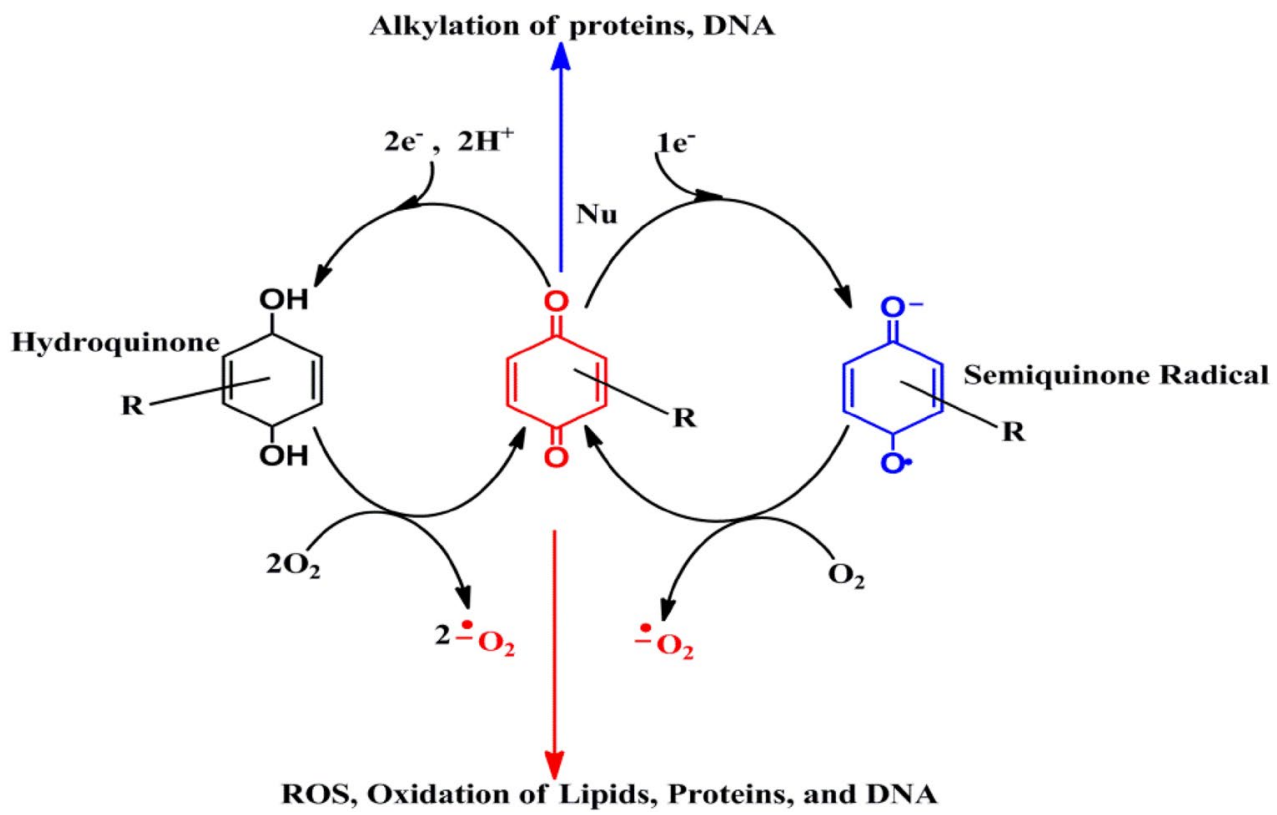

to occur via the cytochrome P450-mediated oxidation or hydroxylation which may cause cellular damage and other grave cancer-related illnesses $[13,40]$. Cancer is one of the most common malignant tumors causing agents in the human biological system and is globally the major cause of morbidity and mortality according to the American Cancer Society-claiming several lives each year [19].

Extreme exposure to PAHs initiates lung cancer because as soon as they enter the lung, they induce phase I metabolic enzyme: cytochrome P450 (CYP) mono-oxygenases, and phase II enzymes-glutathione S-transferases, UDP glucuronyl transferases, NADPH quinone oxidoreductases (NQOs), aldo-keto reductases (AKRs) and epoxide hydrolases (EHs), via the aryl hydrocarbon receptor-dependent and receptor-independent mechanistic pathways [19]. Quinone metabolites from PAHs are highly redox-active molecules and can undergo redox processes with their semiquinone radicals (Fig. 2), leading to the formation of reactive oxygen species (ROS): superoxide, hydrogenperoxide and the hydroxyl radical [24, 38, 40,41]. It is, however, important to note that the parent PAH molecules that find their way into the pulmonary cells are considered pro-carcinogens because they do not directly induce DNA damage, but their corresponding metabolites are responsible for initiating cancer [39].

\section{Conclusions}

This study suspects that the PAH contaminants in the sediments of River Elburgon are associated primarily with the activities of the wood treatment plant located within Elburgon town because the concentrations of these chemicals decreased steadily downstream from Elburgon town. This suggests that there is no other significant additional source of PAHs as the river flows from check points 1-5. Moreover, based on the concentration ratio of high molecular weight $\mathrm{PAH}$ to low molecular weight PAHs which was found to be $>1$, the source of $\mathrm{PAH}$ in the bottom sediment of River Elburgon can be inferred as petrogenic. The predominance of two- and three-ring PAHs in this study also confirms that source is petrogenic. This is because wood preservatives such as creosote and/or pentachlorophenol are a major precursor for PAHs. Benzo[a]pyrene which is a well-known cancer-causing chemical represented $14.57 \%$ of all the $\mathrm{PAHs}$ investigated in this work. Thus, the abundance of benzo[a]pyrene in this study as a marker PAH for carcinogenicity is consistent with other studies reported in the literature. These findings are an indication that the water in River Elburgon is unsuitable not only for drinking, but also unfit for irrigation and industrial purposes. The establishment of a wood treatment plant and use of agrochemicals within Elburgon town are proposed to cause negative effects on water quality. A review of the mechanistic biological action of PAHs based on the findings of this study has been presented to enhance the understanding of the potency of PAHs in water systems and other environments.

Acknowledgements The authors wish to thank the University of KwaZulu-Natal (UKZN), for according JK the opportunity to conduct GCMS analysis. Egerton University (Division of Research and Extension) is also appreciated for facilitating the success of this study. 
Author's contribution JKK designed the project. FEO collected sediments, treated and prepared the samples for analysis under the direction of JKK and SMN and wrote the first draft of the manuscript. SKK drew the map indicating the locations where samples were collected. JKK conducted GCMS analysis, interpreted the data and critically reviewed the manuscript. All authors read and approved the final manuscript.

Funding The authors are grateful to the National Research Foundation (NRF-South Africa) and Egerton University for co-funding this research.

\section{Compliance with ethical standards}

Conflict of interest The authors declare they have no competing interests.

\section{References}

1. Yan X, Zhu Z, LiT (2019) Pollution source localization in an urban water supply network based on dynamic water demand. Environ Sci Pollut Res Int 26:17901-17910. https://doi.org/10.1007/ s11356-017-0516-y

2. Karyab H, Yunesian M, Nasseri S, Mahvi AH, Ahmadkhaniha R, Rastkari N, Nabizadeh R (2013) Polycyclic aromatic hydrocarbons in drinking water of Tehran, Iran. J Environ Health Sci Eng 11:25. https://doi.org/10.1186/2052-336X-11-25

3. Kafilzadeh F (2015) Distribution and sources of polycyclic aromatic hydrocarbons in water and sediments of the Soltan Abad River, Iran. Egypt J Aquat Res 41(3):227-231. https://doi. org/10.1016/j.ejar.2015.06.004

4. Ya ML, Wang XH, Wu YL, Ye CX, Li YY (2014) Enrichment and partitioning of polycyclic aromatic hydrocarbons in the sea surface microlayer and subsurface water along the coast of Xiamen Island, China. Mar Pollut Bull 78(1):110-117. https://doi. org/10.1016/j.marpolbul.2013.10.053

5. Zhao Z, Qin Z, Cao J, Xia L (2017) Source and ecological risk characteristics of PAHs in sediments from Qinhuai River and Xuanwu Lake, Nanjing, China. J Chem. https://doi. org/10.1155/2017/3510796

6. Boonyatumanond R, Wattayakorn G, Togo A, Takada H (2006) Distribution and origins of polycyclic aromatic hydrocarbons (PAHs) in riverine, estuarine, and marine sediments in Thailand. Mar Pollut Bull 52:942-956. https://doi.org/10.1016/j.marpo Ibul.2005.12.015

7. Thompson KL, Picard CR, Chan HM (2017) Polycyclic aromatic hydrocarbons (PAHs) in traditionally harvested bivalves in northern British Columbia, Canada. Mar Pollut Bull 121:390-399. https://doi.org/10.1016/j.marpolbul.2017.06.018

8. Ghosal D, Ghosh S, Dutta TK, Ahn Y (2016) Current state of knowledge in microbial degradation of polycyclic aromatic hydrocarbons (PAHs): a review. Front Microbiol 7:1369. https:// doi.org/10.3389/fmicb.2016.01369

9. Di Toro DM, McGrath JA (2000) Technical basis for narcotic chemicals and polycyclic aromatic hydrocarbon criteria. II. Mixtures and sediments. Environ Toxicol Chem 19:1971-1982. https://doi. org/10.1002/etc.5620190804

10. Yusuf N, Timares L, Seibert MD, Xu H, Elmets CA (2007) Acquired and innate immunity to polyaromatic hydrocarbons. Toxicol Appl Pharmacol 224:308-312. https://doi.org/10.1016/j. taap.2006.12.009

11. Currie $Z$ (2018) Assessing the toxicity of a petroleum-based hydraulic oil to aquatic organisms and the photo-induced toxicity of polycyclic aromatic hydrocarbons in two amphibian species. University of Saskatchewan, Saskatoon

12. Khan S, Waqas M, Ding F, Shamshad I, Arp HPH, Li G (2015) The influence of various biochars on the bioaccessibility and bioaccumulation of PAHs and potentially toxic elements to turnips (Brassica rapa L). J Hazard Mater 300:243-253. https ://doi.org/10.1016/j.jhazmat.2015.06.050

13. Alawi MA, Tarawneh IN, Ghanem Z (2018) Removal efficiency of PAH's from five wastewater treatment plants in Jordan. Toxin Rev 37:128-137. https://doi.org/10.1080/15569 543.2017.1330271

14. Ifegwu OC, Anyakora C (2015) Polycyclic aromatic hydrocarbons: part I. Exposure. Adv Clin Chem 72:277-304. https://doi. org/10.1016/bs.acc.2015.08.001

15. Abdel-Shafy HI, Mansour MSM (2016) A review on polycyclic aromatic hydrocarbons: source, environmental impact, effect on human health and remediation. Egypt J Pet 25:107-123. https ://doi.org/10.1016/j.ejpe.2015.03.011

16. Sadler NC, Webb-Robertson BJM, Clauss TR, Pounds JG, Corley R, Wright AT (2018) High-fat diets alter the modulatory effects of xenobiotics on cytochrome P450 activities. Chem Res Toxicol 31:308-318. https://doi.org/10.1021/acs.chemrestox.8b00008

17. Han J, Won EJ, Kim HS, Nelson DR, Lee SJ, Park HG, Lee JS (2015) Identification of the full 46 cytochrome P450 (CYP) complement and modulation of CYP expression in response to wateraccommodated fractions of crude oil in the cyclopoid copepod Paracyclopina nana. Environ Sci Technol 49:6982-6992. https:// doi.org/10.1021/acs.est.5b01244

18. Stueckle TA, Sargent L, Rojanasakul Y, Wang L (2016) Genotoxicity and carcinogenic potential of carbon nanomaterials. Biomed Appl Toxicol Carb Nanomater. https://doi.org/10.1002/97835 27692866.ch10

19. Moorthy B, Chu C, Carlin DJ (2015) Polycyclic aromatic hydrocarbons: from metabolism to lung cancer. Toxicol Sci 145:5-15. https://doi.org/10.1093/toxsci/kfv040

20. Kim L, Jeon HJ, Kim YC, Yang SH, Choi H, Kim TO, Lee SE (2019) Monitoring polycyclic aromatic hydrocarbon concentrations and distributions in rice paddy soils from Gyeonggi-do, Ulsan, and Pohang. Appl Biol Chem 62(18):1-8. https://doi. org/10.1186/s13765-019-0423-7

21. Dai W, Fu Y, Deng Y, Zeng Z, Gu P, Liu H, Liu J, Xu X, Wu D, Luo X Yang L, Zhang J, Lin K, Hu G, Huang H (2019) Regulation of Wnt singaling pathway by poly (ADP-ribose) glycohydrolase (PARG) silencing suppresses lung cancer in mice induced by benzo(a) pyrene inhalation exposure. Front Pharmacol 10:1-11. https:// doi.org/10.3389/fphar.2019.00338

22. Gupta G, Kumar V, Pal AK (2019) Microbial degradation of high molecular weight polycyclic aromatic hydrocarbons with emphasis on pyrene. Polycycl Aromat Comp 39:124-138. https ://doi.org/10.1080/10406638.2017.1293696

23. Samara F, Khamis M, Sara Z, Elsayed Y (2017) Removal of benzo(a)anthracene from water using a novel UAE sludgebased activated adsorbent. Desalin Water Treat. https://doi. org/10.5004/dwt.2017.21422

24. Antiñolo M, Willis MD, Zhou S, Abbatt JPD (2015) Connecting the oxidation of soot to its redox cycling abilities. Nat Commun 6:6812. https://doi.org/10.1038/ncomms7812

25. Abdel-Shafy HI, Mansour MSM (2016) A review on polycyclic aromatic hydrocarbons: source, environmental impact, effect on human health and remediation. Egypt J Pet 25(1):107-123. https://doi.org/10.1016/j.ejpe.2015.03.011

26. Agrawal PK, Shrivastava R, Verma J (2019) Bioremediation approaches for degradation and detoxification of polycyclic aromatic hydrocarbons in emerging and eco-friendly approaches for waste management. Springer, Berlin, pp 99-119. https://doi. org/10.1007/978-981-10-8669-4_6 
27. Riaz R, Ali U, Li J, Zhang G, Alam K, Sweetman AJ, Jones KC, Malik RN (2019) Assessing the level and sources of polycyclic aromatic hydrocarbons (PAHs) in soil and sediments along Jhelum riverine system of lesser Himalayan region of Pakistan. Chemosphere 216:640-652. https://doi.org/10.1016/j.chemospher e.2018.10.139

28. Laurence M, Kibet JK, Ngari SM (2018) The degradation of o-ethyltoluene and 1,3,5-trimethylbenzene in Lake Naivasha Wetland, Kenya. Bull Environ Contam Toxicol. https://doi.org/10.1007/ s00128-018-2387-4

29. Kibet JK, Khachatryan L, Dellinger B (2015) Phenols from pyrolysis and co-pyrolysis of tobacco biomass components. Chemosphere 138:259-265. https://doi.org/10.1016/j.chemospher e.2015.06.003

30. Keyte IJ, Harrison RM, Lammel G (2013) Chemical reactivity and long-range transport potential of polycyclic aromatic hydrocarbons-a review. Chem Soc Rev 42:9333-9391. https://doi. org/10.1039/C3CS60147A

31. Alexandrov K, Rojas M, Satarug S (2010) The critical DNA damage by benzo(a)pyrene in lung tissues of smokers and approaches to preventing its formation. Toxicol Lett 198:63-68. https://doi. org/10.1016/j.toxlet.2010.04.009

32. Delgado-Saborit JM, Stark C, Harrison RM (2011) Carcinogenic potential, levels and sources of polycyclic aromatic hydrocarbon mixtures in indoor and outdoor environments and their implications for air quality standards. Environ Int 37:383-392. https:// doi.org/10.1016/j.envint.2010.10.011

33. Ferlay J, Colombet M, Soerjomataram I, Mathers C, Parkin DM (2019) Estimating the global cancer incidence and mortality in 2018: GLOBOCAN sources and methods. Int J Cancer 144:19411953. https://doi.org/10.1002/ijc.31937

34. Onozato M, Nishigaki A, Okoshi K (2016) Polycyclic aromatic hydrocarbons in sediments and bivalves on the pacific coast of Japan: influence of tsunami and fire. PLoS ONE 11:e0156447. https://doi.org/10.1371/journal.pone.0156447
35. Wang CH, Wu SH, Zhou SL, Shi YX, Song J (2017) Characteristics and source identification of polycyclic aromatic hydrocarbons (PAHs) in urban soils: a review. Pedosphere 27(1):17-26. https ://doi.org/10.1016/S1002-0160(17)60293-5

36. Wang X-T, Miao Y, Zhang Y, Li Y-C, Wu M-H, Yu G (2013) Polycyclic aromatic hydrocarbons (PAHs) in urban soils of the megacity Shanghai: occurrence, source apportionment and potential human health risk. Sci Total Environ 447:80-89. https://doi. org/10.1016/j.scitotenv.2012.12.086

37. Choi Y, Chatterjee T, Kim J, Kim JS, Cho EJ (2016) Synthesis of cyclopenta-fused polycyclic aromatic hydrocarbons utilizing aryl-substituted anilines. Org Biomol Chem 14:6804-6810. https ://doi.org/10.1039/C6OB01235C

38. Flesher JW, Lehner AF (2016) Structure, function and carcinogenicity of metabolites of methylated and non-methylated polycyclic aromatic hydrocarbons: a comprehensive review. Toxicol Mech Methods 26:151-179. https://doi.org/10.3109/15376 516.2015 .1135223

39. Lerda D (2011) Polycyclic aromatic hydrocarbons (PAHs) factsheet, 4th edn. EuropeanUnion, London

40. Kibet J, Bennadji H, Khachatryan L, Asatryan R (2016) Health and environmental impacts of phenols: the role of radicals. In: Rutherford M (ed) Free radicals and health. Nova Science Publishers Inc., New York, pp 15-45

41. Bolton JL, Trush MA, Penning TM, Dryhurst G, Monks TJ (2000) Role of quinones in toxicology. Chem Res Toxicol 13:135-160. https://doi.org/10.1021/tx9902082

Publisher's Note Springer Nature remains neutral with regard to jurisdictional claims in published maps and institutional affiliations. 